A Út

\title{
A Review: $\quad$ Micro-transition and the agricultural systems in Kashmir Valley
}

\section{Shabeer A. Ganaie and Arshad Bhat}

Article Chronicle: Received :

14.02.2019;

Accepted :

24.05.2019

KEY WORDS:

Transformation, Output, Shift,

Occupational behaviour, Agroecosystems

Author for correspondence :

\section{Arshad Bhat}

Rajiv Gandhi Chair, Shere-Kashmir University of Agricultural Sciences and Technology of Kashmir (J\&K) India

Email: bhatarshad09@

gmail.com

See end of the article for

authors' affiliations
SUMMARY : The Indian economy is having a transitional behaviour. The early transition in the economy took place from feudalism. India had evinced a structural transformation in the overall setup of the economy though has evinced the state of Jammu and Kashmir. But the state has missed the intermediate stage of structural transformation i.e. there is no development of industrial base in the state especially in the Kashmir Valley. The share of agriculture GDP in the state has steadily declined over the last few decades with the result large section of rural workers confined to low productive work and low income.The state has witnessed a drastic sub-sectoral transition from agriculture to horticulture. The present study is a gentle attempt to study different transitions faced by the state of Jammu and Kashmir in General and Kashmir region in particular during the last two-three decades.

How to cite this article : Ganaie, Shabeer A. and Bhat, Arshad (2019). Micro-transition and the agricultural systems in Kashmir Valley. Agric. Update, 14(2): 195-202; DOI : 10.15740/HAS/AU/14.2/195-202. Copyright@ 2019: Hind Agri-Horticultural Society. 